\title{
Third eyelid gland protrusion in dogs. An experimental model proposal
}

\author{
Protrusão da glândula da terceira pálpebra em cães. Proposta de um modelo experimental
}

\author{
Vânia Pais Cabral ${ }^{\mathrm{I}}$ Eduardo Watanabe ${ }^{\mathrm{II}}$ Raimundo Alberto Tostes $^{\mathrm{II}}$ \\ Sandra Maria Simonelli ${ }^{\text {II }}$ José Luiz Laus ${ }^{\text {III }}$
}

\begin{abstract}
The objective of this research was to present an experimental model for the prolapse of the third eyelid gland in male, adult mongrel dogs by the use of a periorbital glandular support conjunctiva tissue resection followed by macro and microscopic assessments. Length, thickness and width of normal glands were statistically studied at baseline and then again after a period of 30 days of exposition. In relation to the experimental model, $84.21 \%$ of glands, which underwent the resection of the conjunctiva support tissue, support tissue, remained protusioned. There were significant differences between normal and protusioned glands. Protusioned glands were larger in respect to length, thickness and width. For the microscopy studies, two experimental groups were established: non-treated protusioned glands (GI); and buried protusioned glands (GII). Glandular, conjunctiva tissue, and duct alterations were studied in both groups. Through the results obtained by the Schirmer's test, it was evidenced that the lachrymal production decreased when compared to the normal ones not protusioned, especially in those cases where the protusioned glands were not buried.
\end{abstract}

Key words: dogs, third eyelid lacrimal gland, protrusion.

\section{RESUMO}

Neste trabalho, propõe-se um modelo experimental de protrusão da glândula da terceira pálpebra em cães mestiços, machos adultos e valendo-se da ressecção do retináculo glandular periorbitário e de avaliações macro e microscópicas. Foram estudadas, a estatística, o comprimento, a espessura e a largura de glândulas normais e após um período de 30 dias de exposição. Relativamente ao modelo experimental, $84,2 \%$ das glândulas em que foi realizada a ressecção do retináculo permaneceram protruídas. Houve diferença significativa entre as glândulas normais e as protruídas. As glândulas protruídas aparentaram-se maiores quanto ao comprimento, à espessura e à largura. Para estudos à microscopia, constituíram-se dois grupos experimentais: glândulas protruídas não-tratadas (GI) e glândulas protruídas sepultadas (GII). Estudaram-se as alterações ductais, as glandulares e as conjuntivais em ambos os grupos. Os resultados mostraram que glândulas protruídas não-tratadas apresentaram maior porcentagem de alterações inflamatórias, glandulares e ductais. Mediante análise do teste de Schirmer I, constatou-se que a produção lacrimal diminuiu, quando comparada às glândulas normais não-prolapsadas, notadamente nos casos em que as glândulas prolapsadas não foram sepultadas.

Palavras-chave: cães, glândula lacrimal da terceira pálpebra, protrusão.

\section{INTRODUCTION}

The tear film helps in the maintenance and integrity of the eyeball surface and the eyelid and eyeball conjunctiva tissues (DAVIDSON \& KUONEN, 2004). The lacrimal and third eyelid, or nictitating, glands are responsible for, respectively, the production of $70 \%$ and $30 \%$, on average, of the aqueous portion of tears (GELLAT, 1991; SAITO et al., 2001).

The third eyelid gland is located on the distal portion of the third eyelid, fixed by a support conjunctiva tissue to the periorbital fascias (CONSTANTINESCU, 2005). Some conditions may

IPrograma de Pós-graduação em Cirurgia Veterinária, Faculdade de Ciências Agrárias e Veterinárias (FCAV), Universidade Estadual Paulista "Júlio de Mesquita Filho" (UNESP), Campus Jaboticabal. Endereço para correspondência: Departamento de Anatomia, Setor Ciências Biológicas, Centro Politécnico, Universidade Federal do Paraná (UFPR). Rua Francisco H. dos Santos, s/n, CP 19031, 81531-990, Curitiba, PR, Brasil. E-mail: vetcabral@gmail.com.

IICurso de Medicina Veterinária, Centro Universitário de Maringá (CESUMAR), Maringá, PR, Brasil.

IIIDepartamento de Clínica e Cirurgia Veterinária, FCAV, UNESP, Campus Jaboticabal, Jaboticabal, SP, Brasil. 
affect the secretion of the lacrimal system and promote qualitative and quantitative alterations in tear films (DAVIDSON \& KUONEN, 2004).

The third eyelid gland protrusion is a condition characterized by the glandular exposition close to the orbit's inferior medial commissure, hyperemia, increase in the gland volume (MORGAN et al., 1993; MOORE, 1998; FARIAS et al., 2001) and ocular discharge and conjunctiva tissue inflammation (MOORE, 1998). There are hypotheses that correlate the occurrence of the third eyelid gland protrusion to the loss of tensile force of the periorbital support conjunctiva tissues (SLATTER, 1990; CONSTANTINESCU, 2005).

GELLAT (1991) states that the third eyelid gland protrusion is more frequent in young animals, up to two years of age, and that it may be uni or bilateral. MOORE (1998) mentions that the third eyelid gland protrusion occurs more frequently in animals belonging to breeds such as the Beagle, American Cocker Spaniel, Boston Terrier, Poodle and brachycephalic dogs.

In respect to therapy, procedures such as the burial or the anchorage of the gland or its surgical exeresis are proposed (FARIAS et al., 2001). It is well documented, however, that the gland's exeresis is one of the causes reported of iatrogenic keratoconjunctivitis sicca in dogs (FARIAS et al., 2001; ALMEIDA et al., 2004).

The objective of this research was to present an experimental model for the prolapse of the third eyelid gland in male, adult mongrel dogs by the use of a periorbital glandular support conjunctiva tissue resection followed by macro and microscopic assessments.

\section{MATERIAL AND METHODS}

Nineteen male, adult mongrel dogs between 2 and 4 years of age, average weight between 8 and 14 $\mathrm{kg}$ were selected after physical (inspection; Schirmer's test I; biomicroscopy; aplanation tonometry; fluoresceine test) and complementary exams (hemogram and biochemical). The animals were vaccinated, vermifuged and individually kept in appropriate cages, receiving water and feed ad libitum. The experimental protocols were conducted obeying the norms established by the Association for Research in Vision and Ophthalmology (ARVO, 1985), and after the approval by the State University of Londrina (UEL) Animal Ethics Committe.

Two experimental phases were conceived. In the first one, the third eyelid gland protrusion experimental model and the macroscopic assessment were carried out. In the second one, histological assessment of the non-treated protrusioned glands and the surgically buried protrusioned glands were performed.

After feed fasting of 12 hours, the animals received acepromazine $\left(0.05 \mathrm{mg} \mathrm{kg}^{-1}\right)$ and morphine $\left(0.2 \mathrm{mg} \mathrm{kg}^{-1}\right)$ intravenously, as pre-anesthetics. Anesthesia was induced by the intravenous administration of thiopental $\left(12.5 \mathrm{mg} \mathrm{kg}^{-1}\right)$, and after endotracheal intubation, inhalatory administration of halothane in closed circuit was conducted.

The third eyelid gland protrusion was induced, bilaterally, by a distal incision of the third eyelid bulbar conjunctiva, followed by the exposition and resection of the periorbital support conjunctiva tissues. During the surgical procedure, a macroscopic assessment of the third eyelid right and left glands was carried out in respect to its length, width and thickness, using a manual pachymeter ${ }^{\mathrm{a}}$. The craniumcaudal, lateral-lateral and dorsal-ventral axes were measured, respectively, for the assessment of the variables. It was established that the protrusioned glands that spontaneously returned to their anatomic place would not be included in the study.

Protrusioned glands were kept for 30 days to be later assessed in respect to the same macroscopic variables, and statically analyzed by Student's t-test System for Elementary Statistical Analysis for paired data. These protocols constituted the first phase of the research.

In the second stage, two groups were conceived (GI e GII). Group GI was composed by the non-surgically buried protrusioned right glands, whereas GII, by the protrusioned left glands buried using the technique proposed MORGAN (1993).

After 30 days, the exeresis of all glands was performed. The samples were fixed in a buffered formalin solution at $10 \%$, dehydrated, embedded in paraffin, serially cut by a rotation microtome with $5 \mu \mathrm{m}$ thick and stained with Hematoxylin - Eosin (HE). The slides were observed in an optical microscope ${ }^{\mathrm{b}}$ with objective of 4x, 10x e 20x in "double blind".

A graduation pattern of tissue alteration according to severity was established. The level and nature of conjunctiva inflammation (lymphoplasmocytes, neutrophiles, granulomatose, neutrophiles-lymphocytes and neutrophilesplasmocytes); duct alterations (inflammation, dilation, scaling metaplasia); and glandular alterations (inflammation, tubular-acinar dilation; atrophy and excess of fat deposition). Concerning the level of severity, the following criteria were used: absence of signs, discrete, moderate and severe signs.

Ciência Rural, v.38, n.7, out, 2008. 


\section{RESULTS}

The conjunctiva support periorbital tissues resection promoted the exposition of $84.2 \%$ of glands in the margin medial corner of the third eyelid. Six cases $(15.7 \%)$ were observed in which the third eyelid gland spontaneously returned to the third eyelid conjunctiva's bulbar fascia. The macroscopic assessment of the normal third eyelid glands showed that the average thickness, width and length corresponded to $0.29 \mathrm{~cm} ; 0.61 \mathrm{~cm} ; 0.98 \mathrm{~cm}$, respectively (Table 1). In respect to the protrusioned third eyelid glands, the averages were $0.36 \mathrm{~cm}$ thick, $0.77 \mathrm{~cm}$ wide and $1.22 \mathrm{~cm}$ long (Table 1 ).

Protrusioned glands showed significant alterations $(\mathrm{P}<0.01)$ in the cranial-caudal dimension (length), lateral-lateral (width), and dorsal-ventral (thickness), comparatively to their normal values before being protrusioned (Figure 1).

As far as the histological assessments were concerned, duct, glandular and conjunctive inflammation were observed in the samples in both group GI and in GII. In relation to the nature of inflammation it was noticed that the glands presented granulomatose alterations $6.2 \%$, neutrophilesplasmocytes $3.1 \%$; lymphocytes $18.7 \%$; neutrophileslymphocytes $25 \%$ and lympho-plasmocytes $46.8 \%$. In GI, the greater percentage of inflammatory alterations was of neutrophiles-lymphocytes type (37.5\%), whereas in group GII a greater percentage was of the lympho-plasmoticytes type (62.5\%) (Table 2).

According to the graduation pattern conceived to quantify the severity of tissue alterations, it was possible to identify that in GI $56.2 \%$ discrete inflammatory alterations, $18.7 \%$ moderate and $25 \%$ severe were observed (Table 3). In GII, $62.5 \%$ discrete inflammatory alterations, $12.5 \%$ moderate, and $18.7 \%$ severe were identified. In $6.2 \%$ they were absent (Table 3).

Concerning glandular alterations, in GI $18.7 \%$ had discrete glandular alterations, $75 \%$ moderate and $6.2 \%$ severe (Table 3 ). In GII, $75 \%$ of the alterations identified were classified as discrete, $12.5 \%$ moderate and $12.5 \%$ severe (Table 3 ).
In respect to the ducts, in GI, $31.2 \%$ of the glands had discrete duct alterations, $62.5 \%$ moderate and $6.2 \%$ severe (Table 3 ). In GII, $62.5 \%$ of the alterations identified were classified as being discrete, $46.7 \%$ moderate and $6.2 \%$ severe (Table 3 ).

The averages of tear production, in the bulbs of the normal eyes right and left had been, respectively, $21.2 \pm 2.7 \mathrm{~mm} \mathrm{~min}^{-1}$ and $21.0 \pm 3.1 \mathrm{~mm} \mathrm{~min}^{-1}$. After the accomplishment of the experimental model of third eyelid gland protrusion, the average of the production of tear in GI was of $18.4 \pm 4.0 \mathrm{~mm} \mathrm{~min}^{-1}$ and in GII was of $20.9 \pm 3.5 \mathrm{~mm} \mathrm{~min}^{-1}$.

\section{DISCUSSION}

The third eyelid gland protrusion is also described as protrusion, hypertrophy, glandular hyperplasia, nictitating gland adenoma or cherry eye. It is a condition that has been reported in dogs for more than 40 years (MORGAN et al., 1993). Although the cause is still controversial, support conjunctiva tissue abnormalities or the loss of tensile force that anchors the gland to the periorbit has been proposed as a predisposing condition (MORGAN et al., 1993; CONSTANTINESCU, 2005).

In this research, it was demonstrated that in $84.2 \%$ of glands, on which the periorbital support conjunctiva tissue resection took place, they remained protrusioned in the free edge of the third eyelid. It was evidenced, however, six cases (15.2\%) of spontaneous topographic return to the third eyelid internal face, which had also been described by SLATTER (1990), in clinical cases.

In the macroscopic assessment of the third eyelid glands of normal male dogs, CABRAL et al. (2005) mentioned averages of $1.29 \mathrm{~cm}$ long, $0.8 \mathrm{~cm}$ wide and $0.42 \mathrm{~cm}$ thick. In the present study, however, it was observed averages of $0.98 \mathrm{~cm}$ long, $0.61 \mathrm{~cm}$ wide and $0.29 \mathrm{~cm}$ thick. The differences in respect to the parameters may be correlated to the number in the sample. In that study the sample was composed by 14 , whereas in this study was 32 .

Table 1 - Macroscopic assessment of the third eyelid normal and protrusioned glands of male, adult mongrel dogs (Canis lupus familiaris, Linnaeus 1758), in respect to length, width, and thickness.

\begin{tabular}{lccc}
\hline \multirow{2}{*}{ Glandular sample } & - & & \\
& Length $(\mathrm{cm})$ & Width $(\mathrm{cm})$ & Thickness $(\mathrm{cm})$ \\
\hline Normal Glands & $0.98 \pm 0.17$ & $0.61 \pm 0.16$ & $0.29 \pm 0.08$ \\
Protrusioned Glands & $1.22 \pm 0.21$ & $0.77 \pm 0.16$ & $0.36 \pm 0.12$ \\
\hline
\end{tabular}

Student's t-test $(\mathrm{P}<0.01)$. 

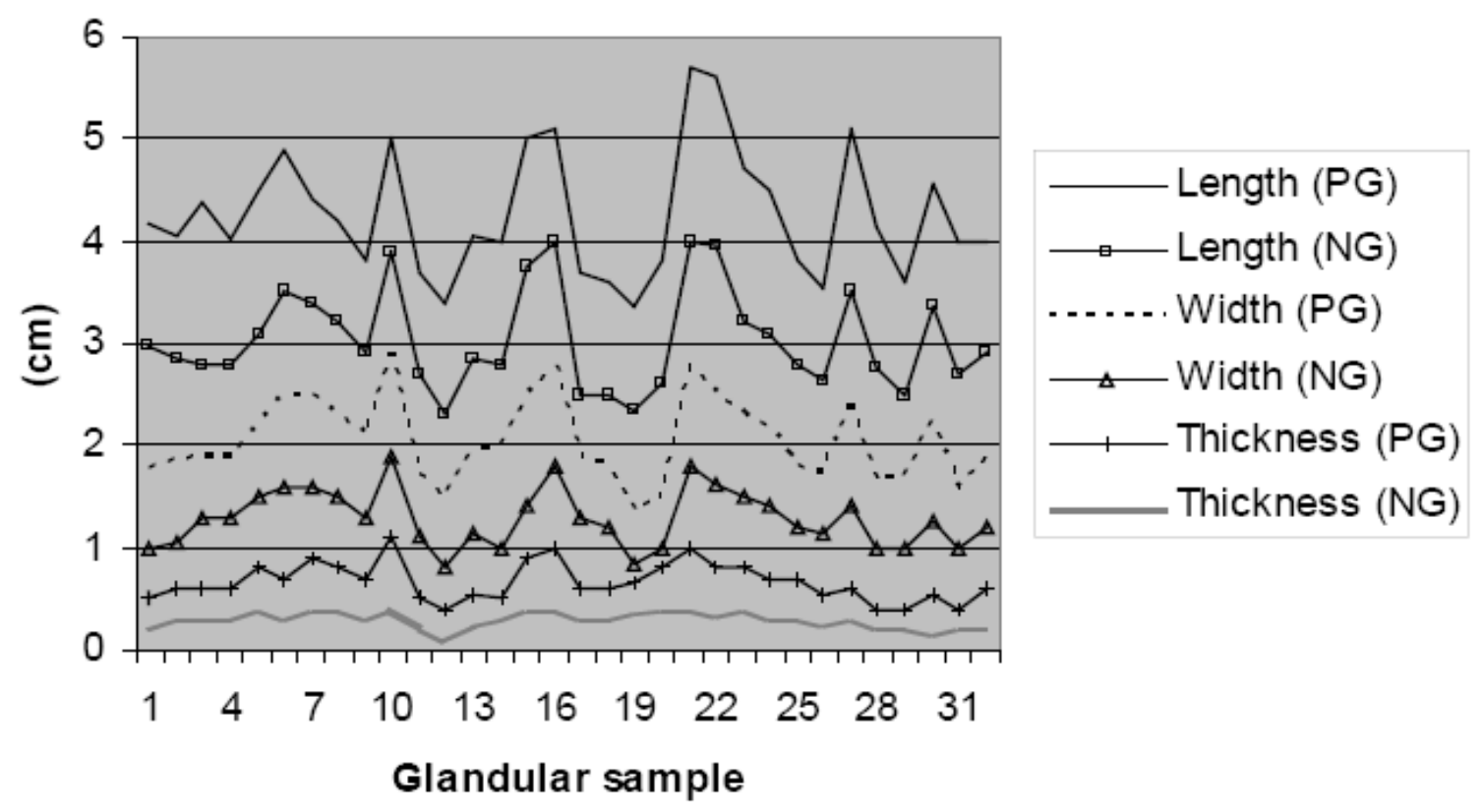

Figure 1 - Graphic representation of the macroscopic assessment of normal (NG) and protrusioned glands (PG) thickness, length and width in male, adult mongrel dogs (Canis lupus familiaris, Linnaeus 1758).

GELLAT (1991) and MOORE (1998) stated that the increase in glandular volume is a consequence of abrasion and drying promoted by exposition. In this study, it was possible to observe that there were significant differences in respect to the variables studied.

DUGAN et al. (1992) reported discrete inflammatory alterations in non-treated protrusioned lacrimal glands, excised or surgically repositioned. In the present study, however, the inflammatory alterations identified were discrete, moderate and severe.

The burial surgical technique described by MORGAN (1993), adopted in this study, was based in the employment of the conjunctiva bulbar face tissue for incision and repositioning of glands. However, it is known that the third eyelid lacrimal gland excretory ducts are located in the conjunctiva's bag close to the basis of the third eyelid (KASWAN et al., 1984). It has been observed that $62.5 \%$ of protrusioned glands presented moderate duct alterations. In the treated protrusioned glands, $62.5 \%$ of alterations were classified as discrete and there was just one case in that was considered severe.

Corroborating the DUGAN findings et al. (1992), in the analysis of the Schirmer test results, it was evidenced that the lacrimal production diminished, when compared with the normal ones not protrusioned, mainly in those cases where the prolapsed glands were not buried.

Table 2 - Assessment in respect to the nature of protrusioned third eyelid glands conjunctiva tissue inflammatory infiltrate (GI), and those protrusioned and surgically buried (GII) in male, adult mongrel dogs(Canis lupus familiaris, Linnaeus 1758).

\begin{tabular}{|c|c|c|c|c|c|c|}
\hline \multirow{2}{*}{$\begin{array}{l}\text { Nature of the connective } \\
\text { tissue infiltrate }\end{array}$} & \multicolumn{2}{|c|}{--------------GI-------------- } & \multicolumn{2}{|c|}{-------------GIII------------- } & \multicolumn{2}{|c|}{-------------Total------------- } \\
\hline & Percentage & Number of cases & Percentage & Number of cases & Percentage & Number of cases \\
\hline Lymphoplasmocytes & $31.2 \%$ & 5 & $62.5 \%$ & 10 & $46.8 \%$ & 15 \\
\hline Lymphocytes & $18.7 \%$ & 3 & $18.7 \%$ & 3 & $18.7 \%$ & 6 \\
\hline $\begin{array}{l}\text { Neutrophiles- } \\
\text { plasmocytes }\end{array}$ & $6.2 \%$ & 1 & 0 & 0 & $3.1 \%$ & 1 \\
\hline $\begin{array}{l}\text { Neutrophiles- } \\
\text { lymphocytes }\end{array}$ & $37.5 \%$ & 6 & $12.5 \%$ & 2 & $25 \%$ & 8 \\
\hline Granulomatose & $6.2 \%$ & 1 & $6.2 \%$ & 1 & $6.2 \%$ & 2 \\
\hline Total & $100 \%$ & 16 & $100 \%$ & 16 & $100 \%$ & 32 \\
\hline
\end{tabular}


Table 3 - Assessment of severity level in the connective tissue inflammation process, glandular and duct alterations in protrusioned (GI*) and protrusioned and surgically buried (GII**) third eyelid glands in male, adult mongrel dogs (Canis lupus familiaris, Linnaeus 1758).

\begin{tabular}{|c|c|c|c|c|c|c|c|c|}
\hline \multirow{2}{*}{$\begin{array}{l}\text { Groups } \\
\text { Severity level (\%) }\end{array}$} & \multicolumn{4}{|c|}{ 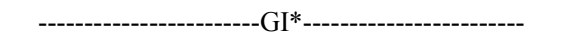 } & \multicolumn{4}{|c|}{ 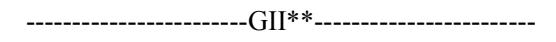 } \\
\hline & Absent & Discrete & Moderate & Severe & Absent & Discrete & Moderate & Severe \\
\hline Inflammatory infiltrate & 0 & 56.2 & 18.7 & 25.0 & 6.25 & 62.5 & 12.5 & 18.75 \\
\hline Glandular alterations & 0 & 18.7 & 75.0 & 6.25 & 0 & 75.0 & 12.5 & 12.5 \\
\hline Duct alterations & 0 & 31.2 & 62.5 & 6.25 & 0 & 62.5 & 31.0 & 6.25 \\
\hline
\end{tabular}

* After 30 days of the protrusion; ** After 30 days of the surgically buried.

\section{CONCLUSIONS}

Based on the results obtained in this study it is possible to state that: the periorbital conjunctiva support tissue resection is a viable technique and capable of promoting an experimental model protrusion of the third eyelid gland in dogs. Protrusioned glands that were not buried presented a greater percentage of duct and glandular inflammatory alterations and lower production of the tear, when compared to those surgically buried.

\section{SOURCES OF ACQUISITION}

aPachymeter: Stainless Hardened.

bikon Eclipse E 800.

\section{ACKNOWLEDGEMENTS}

The authors would like to thank the students and trainees at Maringa's Universitary Center (CESUMAR) Veterinary Hospital; Manfrim feed industry; those responsible for the Research Sector at Maringa's University Center (CESUMAR) Veterinary Hospital for their financial support and for providing the conditions for this study. In the same way, we would like to thank the Coordination for Higher Level Personal Development (CAPES).

\section{REFERENCES}

ALMEIDA, D.E. et al. Iatrogenic keratoconjunctivitis sicca in a dog. Ciência Rural, v.34, p.921-924, 2004.

ARVO. Health research extension act of 1985 public law 99-158. Zero hora digital, Fort Lauderdale, 08 abril. 2008. Online. Disponível na internet: htpp: // www.arvo.org/eweb/ dynamicpage.aspx

CABRAL, V.P. et al. Canine lacrimal and third eyelid superficial glands' macroscopic and morphometric characteristics. Ciência Rural, v.35, n.2, p. 391-397, 2005.
CONSTANTINESCU, G.M. Olho e pálpebras. In: Anatomia clínica de pequenos animais. Rio de Janeiro: Guanabara, 2005. Cap.2, p.115-118.

DAVIDSON, H.J.; KUONEN, V.J. The tear film and ocular mucins. Veterinary Ophthalmology, v.7, n.2, p.71-77, 2004.

DUGAN, S.J. et al. Clinical and histologic evaluation of the protrusioned third eyelid gland in dogs. Journal American Veterinary Medication Association, v.201, n.12, p.18611867,1992 .

FARIAS, V.M. et al. Correção cirúrgica de protrusão de glândula de terceira pálpebra - Relato de um caso. Ciência Animal, v.11,n.2, p.162-164, 2001.

GELLAT, K.N. Canine lacrimal and nasolacrimal diseases. In: Veterinary ophthalmology. 2.ed. Philadelphia: Lea \& Febiger, 1991. Cap.7, p.276-289.

KASWAN, R.L. et al. Keratoconjunctivitis sicca: histopathologic study of nictitating membrane and lacrimal gland from 28 dogs. American Jouranl Veterinary Research, v.45, n.1, p.112117,1984 .

LINNAEUS, C. Systema nature. Provenienza: Holmiae, 1758. 2v.

MOORE, C.P. Terceira pálpebra. In: SLATTER, D. Manual de cirurgia de pequenos animais. 2.ed. São Paulo: Manole, 1998. V.2, p.1428-1435.

MORGAN, R.V. et al. Protrusion of the gland of the third eyelid in dogs: a retrospective study of 89 cases (1980 to 1990). Journal of the American Animal Hospital Association, v.29, p.56-60, 1993.

SAITO, A. et al. The effect of third eyelid gland removal on the ocular surface of dogs. Veterinary Ophthalmology, v.4, n.1, p.13-18, 2001.

SLATTER, D. Third eyelid. In: SLATTER, D. Fundamentals of veterinary ophthalmology. 2.ed. Philadelphia: Saunders, 1990. p.227-234. 